\title{
Evaluation of Protein Profiles, Bioactivity, Allergenicity and Toxicity of Peptides Generated After in silico Digestion of Common Wheat and Einkorn Wheat
}

\author{
Pelin Sultan Perçin ${ }^{1, a, *}$, Sibel Karakaya ${ }^{1, b}$ \\ ${ }^{1}$ Department of Food Engineering, Faculty of Engineering, Ege University, 35100 Izmir, Turkey
} *Corresponding author

A R T I C L E I N F O
Research Article
Received : 12/11/2019
Accepted : 25/02/2020

Keywords: ACE inhibitory DPP IV inhibitory Triticum aestivum Triticum monococcum Possible bioactive peptide A B S T R A C T
The belief that ancient wheat is more beneficial than common wheat has been growing trend in recent
years among the consumers. The present study aims to compare bioactive peptide, allergen peptide
and toxic peptide generation after gastrointestinal digestion of modern wheat (Triticum aestivum)
and ancient wheat, einkorn (Triticum monococcum var. monococcum), using in silico tools. The
primary sequences of both kinds of wheat were obtained from BIOPEP-UWM and
UniProtKB/Swiss-Prot database. In silico digestion was applied using BIOPEP-UWM online tool.
For the simulation of gastrointestinal digestion pepsin (pH 1.3) (EC 3.4.23.1), trypsin (EC 3.4.21.4),
and chymotrypsin (EC 3.4.21.1) were selected and analyzed. Homology analysis was performed for
each protein sequences using EMBOSS Needle program. Toxic and allergen peptides were predicted
using ToxinPred online tool and Allergen FP v.1.0. The results showed that einkorn and common
wheat proteins exhibited similar properties including high similarity rate (58.72-87.40\%) indicating
the percentage of matches between the two sequences and the identical bioactivities for peptides
generated after digestion. Most of the bioactive peptides were dipeptides and the majority of them
displayed more than one bioactivities including ACE inhibitory, DPP IV inhibitory or antioxidant
activity, etc. Allergen peptides generated after in silico digestion were found to be similar for both
kinds of wheat. In silico gastric digestion of einkorn and wheat caused toxic peptides production,
but they were disappeared after in silico intestinal digestion. In conclusion, although there is a
perception related to the Einkorn that is healthier than common wheat, in silico digestion of common
wheat and einkorn did not support this perception.

\section{Introduction}

Bioactive peptides have been defined as specific protein fragments with several health benefits and have a positive impact on body functions. They can release from food proteins after several processes such as enzymatic hydrolysis, fermentation, heat, and high-pressure treatments or during gastrointestinal digestion (Garg et al., 2018; Tu et al., 2018). In recent years, in silico approaches have been utilized to predict and design various bioactive peptides released from food-derived proteins (Darewicz et al., 2016; Kȩska and Stadnik, 2016; Tulipano et al., 2015; Udenigwe, 2016). This approach combines statistical techniques, biology, math and computer science for analysis and evaluation of biological data (Valdés et al., 2017). In silico tools can be used with various purposes when studying about bioactive peptides (BAPs). For example, UnıProt, SwissProt and TrEMBL databases can provide sequences of food proteins while BIOPEP-UWM and PepBank databases can predict bioactive peptides (Garg et al., 2018). BIOPEP-UWM and ExPASy-
PeptideCutter online tools are useful to select specific enzymes and proteins. Among these online tools, BIOPEPUWM offers different functions including databases of protein sequences, sensory peptides, bioactive peptides, etc. (Minkiewicz et al., 2019). This program enables for hydrolysis of food proteins with selected enzyme or enzyme combinations and comparison of the bioactivities of released peptides with known bioactive sequences found in the literature and/or different databases. BIOPEP-UWM has 3792 bioactive peptide sequences (accessed June 2019) with different activities including antibacterial, antioxidant, dipeptidyl peptidase IV inhibitor (DPP IV inhibitor) and angiotensin-converting enzyme inhibitor (ACE-I). Also, BIOPEP-UWM can calculate the incidence of BAPs in a protein chain. Another program, PeptideRanker, evaluates the activity of released peptides by assigning scores between 0 and 1 , to which, the score close to 1 corresponding to high activity. In silico tools also enable to predict allergenicity and toxicity of released 
peptides. AlgPred, Allergen FP v.1.0 and/or AllerTop can predict allergenicity and ToxinPred can predict toxicity. Bioinformatics tools utilize two approaches, namely sequence similarity and motif combination to predict allergen proteins or peptides. AlgPred, APPEL, AllerTOP, AllergenFP are in silico tools working by using these approaches. Generally, AllergenFP is preferred since its higher sensitivity, accuracy, and specificity than others (Dimitrov et al., 2014).

Cereals, the main energy source of human nutrition, are grown in many regions around the world (Cavazos and Gonzalez de Mejia, 2013). The major wheat species grown throughout the World, Triticum aestivum, generally called as bread wheat or common wheat is a hexaploid species. Triticum var. durum is another species of wheat, which is mainly used for making pasta and known as pasta wheat or durum wheat. In addition to these species' other ancient wheat species, which are only grown in small areas, have been becoming a popular as they have been proposed to be rich sources of bioactive compounds and therefore suitable for producing a high value of food products with enhanced health benefits. The most popular one in Turkey is the diploid wheat einkorn (Triticum monococcum var. monococcum). Archeological findings show that wheat first occurred in parts of Turkey, Lebanon, Syria, the Levant, Israel, Egypt, and Ethiopia. Domesticated Einkorn wheat in Turkey dates back to 9000 BC (Cooper, 2015).

The identification study by DNA fingerprinting shows that the wild group of Triticum monococcum boeoticum, which is cultivated about 10000 years ago in Karacadağ Mountain (Turkey) can be a probable progenitor of diploid $(2 n=14)$ einkorn. The einkorn wheat is rich in protein, lipid, antioxidant compounds, and carotenoids, especially lutein and it can be a suitable choice for developing new functional foods because of its nutritional value (Hidalgo and Brandolini, 2014). The data available for ancient wheat species have been related to mostly on their dietary fiber contents (Brandolini and Hidalgo, 2011; Gebruers et al., 2008; Lùje et al., 2003), phytochemicals such as phenolics, carotenoids, and tocols (Grausgruber et al., 2004; Lachman et al., 2013; Shewry and Hey, 2015). Dietary fiber and major groups of phytochemicals in 5 lines of einkorn, emmer, and 161 wheat cultivars were investigated in the HEALTHGRAIN project, which is the largest study comparing ancient and modern wheat. Data showed that ancient wheat cultivars are generally lower in some components such as dietary fiber and higher in other components like polyphenols. Besides, the protein level of einkorn wheat was found to be higher than those of modern wheat in HEALTHGRAIN project (Shewry and Hey, 2015).

Till date, the best of our knowledge no studies about bioactive peptides produced by the consumption of einkorn wheat have been explored although they have been suggested as a healthier choice and a better nutritional profile than modern wheat. However, studies on the bioactive peptides' generation from different protein sources have been intensified recently due to their beneficial effects on health including antihypertensive, cholesterol-lowering, antioxidant, and anti-inflammatory effects (Tu et al., 2018; Udenigwe and Aluko, 2012).

This study aimed to compare bioactive peptide generation after gastrointestinal digestion of modern wheat (Triticum aestivum) and ancient wheat, einkorn (Triticum 902 monococcum var. monococcum), using in silico tools. In addition, allergenicity and toxicity of peptides generated from in silico digestion were predicted.

\section{Methods}

Protein Sequences of Wheat (Triticum aestivum) and Einkorn (Triticum Monococcum var. monococcum) Storage Proteins

Wheat proteins can be classified metabolic proteins like enzymes and non-metabolic proteins like storage proteins. Gliadin and glutenin, which are non-metabolic storage proteins, create $90 \%$ of the total protein content (Žilić et al., 2011). Therefore, these storage proteins were analyzed in the assays. The primary sequences of the wheat storage proteins (low molecular weight glutenin, $\omega$-gliadin, $\gamma$ gliadin and $\alpha$-gliadin) were obtained from BIOPEP-UWM database and high molecular weight glutenin was obtained from UniProtKB/Swiss-Prot and TrEMBL databases. The primary sequences of einkorn storage proteins (high molecular weight glutenin, low molecular weight glutenin, $\omega$-gliadin, $\gamma$-gliadin, $\alpha$-gliadin and avenin like protein) and their accession numbers were obtained from UniProtKB/Swiss-Prot and TrEMBL databases in the FASTA format.

\section{Sequences Alignment by EMBOSS Needle (EMBL- EBI) Analysis}

Homology analysis was performed for each protein sequences of wheat and einkorn in FASTA format. Structural, functional and/or evolutionary relationships between two biological sequences (protein or nucleic acid) can be indicated by identify regions of similarity via pairwise sequence alignment. EMBOSS Needle was used for align these sequences. This program reads two input sequences and write their optimal global sequence alignment along their entire length to the file via Needleman-Wunsch alignment algorithm. The algorithm uses a dynamics programming method to ensure the alignment is optimum, by exploring all possible alignments and choosing the best conditions and a scoring matrix is read that contains values for every possible residue or nucleotide match (Needleman and Wunsch, 1970). Local or global pairwise alignments methods can be used with this tool and as a result of this analysis some information can be generated like scores, identity, similarity and gaps (Chojnacki et al., 2017). Proteins which have been similar amino acid sequences regions mean these proteins can be generated similar potential bioactive peptides (Vercruysse et al., 2009). This high similarity rate indicates that the peptides obtained in silico analysis applied to one of the proteins compared can be identified in the other protein. The similarity means the percentage of matches between the two sequences over the reported align region including any gaps in the length. Although the similarity is high, the same peptides may not be produced using the same enzymes. Therefore, each protein should be analyzed independently (Lafarga and Hayes, 2014). For the analysis, protein sequences of wheat and einkorn were entered into the program and the analysis was performed by selecting optimal parameters for protein align; Matrix (EBLOSUM62), Gap penalty (10.0) and Extend penalty (0.5). 


\section{Amino Acid Compositions Analysis}

ProtParam tool which is an in silico analysis program that gives the amino acid compositions and some physicochemical properties of proteins or peptides was used to evaluate amino acid compositions of wheat and einkorn storage proteins.

In Silico Assessment

Proteolysis, bioactivities and frequency of occurrence of bioactive peptides

BIOPEP-UWM database hosted by Warmia and Mazury University, Olsztyn, Poland was used for simulated proteolysis of wheat and einkorn storage proteins (Minkiewicz et al., 2019). BIOPEP-UWM database was used for the analysis of wheat storage proteins. First, "enzyme action" tool was selected and in "protein database" section wheat protein sequences were chosen. For einkorn proteins, amino acid sequences of each protein copied from UniProtKB, were entered "for your sequence" section on BIOPEP-UWM tool. For the simulation of gastric digestion of proteins pepsin (EC 3.4.23.1) was selected on "enzyme action" tool. Afterward, for the simulation of gastrointestinal digestion pepsin $(\mathrm{pH}$ 1.3) (EC 3.4.23.1), trypsin (EC 3.4.21.4), and chymotrypsin (EC 3.4.21.1) were selected and analyzed. Theoretically, released peptides were obtained and they were submitted to "search for active fragments" and "calculate $A_{E}, D H t, W, B E, V$ " section. After calculation of the bioactivities of released peptides, the classification was made according to the activities and the second classification was made according to their mono and multifunctional properties. A monofunctional peptide refers to a peptide that represents only a single bioactivity. However, the multifunctional peptide may exhibit more than one bioactivity such as ACE inhibitory, DPP-IV inhibitory and opioid activities. Some parameters including the theoretical degree of hydrolysis (DHt), the frequency of release of fragments with a given activity by selected enzymes $\left(\mathrm{A}_{\mathrm{E}}\right)$ and the relative frequency of the release of fragments with a given activity by selected enzymes (W) and values were calculated after proteolysis using the following equations (Minkiewicz et al., 2019):

$$
\begin{aligned}
& A_{E}=d / N \\
& W=A_{E} / A
\end{aligned}
$$

Where $\mathrm{d}$ is the number of fragments released by enzymes with a given activity from a given protein sequence, $\mathrm{N}$ is the total number of amino acid residues in a protein chain, and $\mathrm{A}$ is the frequency of bioactive fragments occurrence in protein sequence.

Toxicity and allergenicity prediction

The toxicity and the allergenicity of the peptides released after gastric and gastrointestinal proteolysis were predicted using the ToxinPred online tool and Allergen FP v.1.0 tool respectively. These tools were also used to predict the toxicity and allergenicity of the bioactive peptides.

Peptide ranking and bioactivity prediction

PeptideRanker online tool was used to determine activity score of bioactive peptides. The peptides with a score of more than 0.5 were considered as positive results in the present study.

\section{Results and Discussions}

\section{Compositions and Homology of Selected Proteins}

Protein profiles of wheat and einkorn and their sequences were obtained from BIOPEP-UWM and UniProt databases to determine peptide release and their activities (bioactivity, allergenicity, and toxicity) after in silico digestion. Five storage proteins of wheat and six storage proteins of einkorn were achieved. Table 1 shows protein sequences of einkorn (Triticum monococcum) and wheat (Triticum aestivum) obtained from UniProt and BIOPEP-UWM databases, respectively.

Figure 1 shows the theoretically calculated percentage of amino acids in wheat storage proteins. The predominant amino acid of all wheat storage proteins was glutamine. The highest percentage of glutamine was found in LMW glutenin $(39.2 \%)$ whereas $\gamma$-gliadin (32.6) contained the least percentage of glutamine. In addition, wheat storage proteins are rich sources of serine (5.4-9.3\%), valine (0.7$5.3 \%)$, proline $(12.8-26.8 \%)$, phenylalanine (0.4-8.9\%), leucine $(4.6-8.6 \%)$, isoleucine $(2.9-5.7 \%)$, and alanine $(2.1$ $-4.5 \%)$.

Similar to wheat storage proteins glutamine was the predominant amino acid in all of the storage proteins of einkorn. However, the highest percentage of glutamine $(40.8 \%)$ was found in $\omega$-gliadin (Figure 1). The glutamine percentage of avenin like protein was 25.4. The other amino acids of einkorn storage proteins were serine (4.2$8.6 \%$, proline $(7.7-27.3 \%)$ and aliphatic neutral amino acids like valine $(2.3-5.2 \%)$, alanine $(3.1-9 \%)$, isoleucine (0.6-5.8\%), leucine (5.3-9.5\%), and aromatic amino acids such as phenylalanine (0.4-7.5\%). Pooja et al., 2017 and Szerszunowicz and Nalecz, 2018, reported the abundance of glutamine in different cereals' proteins. Similar to our results oat globulins predominantly contained glutamine and aliphatic amino acids (Szerszunowicz and Nalecz, 2018) and the predominant amino acid of rice bran globulin and prolamin was glutamine (Pooja et al., 2017).

Similarities and differences among the storage proteins of wheat and einkorn were shown in Table 2. Sequence similarity analysis compares similar regions between two protein sequences (Lafarga and Hayes, 2014) and the "identity" explains the percentage of matched amino acids in the total length of the aligned sequences. Greater values refer to the homology among the protein sequences (Altschul et al., 2005). The results of analyses showed that gliadin proteins and glutenin proteins of both kinds of cereals were similar ranges between 58.2 and $87.4 \%$. Due to high similarities between the same proteins of wheat and einkorn, the release of peptides with the same sequences and activities after in silico digestion might be expected.

\section{Allergenicity and Toxicity Prediction}

Allergenicity of food proteins is one of the major health concerns associated with the consumption of new foods, supplements, etc. (Dimitrov et al., 2014; Rahaman et al., 2016). Generally, allergen proteins can resist to pepsin hydrolysis. Therefore, it is important to exert how gastrointestinal digestion can affect the release of allergen peptides. In addition, these proteins are generally thought to be resistant to proteolysis in the intestine, and some of them are partially heat-resistant. 
Table 1 Storage proteins of einkorn and wheat and their sequences ${ }^{c}$

\begin{tabular}{c|c} 
Einkorn Storage Protein (ID ${ }^{\mathrm{a}}$ ) & Amino Acid Residues \\
HMW glutenin (A0A0M4FY26) & 809 \\
\hline
\end{tabular}

MTKRLVLFAAVVVALVALTAAEGEASGQLQCERELQKHSLKACRQVVDQQLRDVSPECQPVVVGPVARQYEQQVVVPPKGGSFYPGETTPPQQLQQ SILWGIPALLKRYYLSVTSPOQVSYYPGQASSOOSGQROOEYYLTSPOQPEOWOQPGOGOSAYYPTSPOQPGOKOPRYYPTSPWOPGQLOQPTOGOQR QQLGQGQQLRQGQQGQQSGQGQLRYYPTFSQQSGQLQQLAQGQQGQQPERGQQGQQSGQGQQLGQGQQGQQPGQKQQSGQGQQGYYPISPQQLG QGQQSGQGQQSGQGQLGYYPTSPQQSGQGQSGYYPISAQQPGQLQQPTQEQQLGQEQQDQQPGQGQQGQESGQRQQDQQSRQGQQPGQRQPGYYS TSPOQSGQGQPRYYPTSPQQPGQEOQPROLOQPEQGQQGEOPEQGOQGQQPGQGEOGQQPGQGQQGQQLGQGOPGYYPTSPQQSGOGOPGYYPTSP QQPGQLQQPAQGQQPGQEQQGQQPGQGQQPGQGQPGYYPTSPQQSGQGQQLGQWQQSGQGQPGHYPTSPLQPGQGQPGYYPTSPQQIGQGQQPGQL QQPTQGQQGQQPGQGQQGQQPGQGQQGQQPGQGQPGYYPTSPQQSGQGQQPGQWQQPGQEQPGYHPTSSLQSGQGQQGYYPTSQQQPGQGPQPGQ WOOSGOGOQGYYPTSPQQSGQGQQPGQWLOPGQGQQGYYLTSPRQLGQGQQPRQWLQPRQGQQGYYPTSPQQQLGQGQQGYYPTSPQQPGQGQQ GYDSPYHVSAEHQAASLKVAKAQQLAAQLPAMCRLEGGDALLASQ Einkorn Storage Protein $\left(\mathrm{ID}^{\mathrm{a}}\right)$

LMW glutenin (B8XU50) Amino Acid Residues 349

MKTFLVFALLALAAASAVAQISQQQQPPLFSQQQQPPFSQQQQPPFSQQQQSPFSQQQQPPFSQQQQPPFSQQPPISQQQQPQFLQQQQPPFSQQQQPPFS QQQQPPYSQQQQPPFSQQQQPPFSQQQQPPFSQQQQQQPPFTQQQQPPISQQQQPPFSQQQQPPFSQQQQIPVIHPSVLQQLNPCKVFLQQQCIPVAMQQC LARSQMLQQSICHVMQQQCCQQLRQIPEQSRHESIRAIVYSIILQQQQQQQQQQQGQSIIQYQQQQPQQLGQCVSQPQQQLQQQLGQQPQQQQLTHGAF LQPHQIAQLEVMTSIALRNLARMCSVNVALYETTTSVPLGVGIGIGVY

\begin{tabular}{c|c}
\hline Einkorn Storage Protein $\left(\mathrm{ID}^{\mathrm{a}}\right)$ & Amino Acid Residues \\
$\omega$-gliadin (D6QY51) & 348 \\
\hline
\end{tabular}

ARQLNPSNKELQSPQQSFFHQQQPFPTQQSYPQQPYPQQPYSSQQPFPTIQQQFSQQPQQPFPQPQQPIPLQPQQPFPQQSQQPFPQPQQPFSWQPQQPSPL QPQQPFPQPQLPLPQQPEQIIPQQSQQPFPLQAQQPFPQPQQPFPHQPQQQFPQPQQPTPLQPQLPFPQQPQQPFPQPQQQFPWQPQQPFSQPQQPIPQQPQQ VFPLQPQQPFPQQLQQPFPQQPQQLFPQPEQPFPQQSQQLPLQPQQPFSQQPQQSQQSFPQPQPRQPQQPSILQPQQPLPQQPQQPHQSFIQPQQPLPQQA EQIISKQPQQPSPQQPHQPQQPYLQQQQQPSGSSVIGIGGQ

\begin{tabular}{c|c} 
Einkorn Storage Protein $\left(\mathrm{ID}^{\mathrm{a}}\right)$ & Amino Acid Residues \\
$\gamma$-gliadin (B8XU38) & 311 \\
\hline
\end{tabular}

MKTLLILTIIAVALTTTTANIQVNPSSQVQWPQQQQPFPQLQQPFSQQPQQIFPQPQQTFPHQPQQAFPQPQQTFPHQPQQQFPQPQQPQQPFPQQPQQQFP QPQQPQQPFPQPQQPQLPFLQQPQQPFPQPQQPQQPFPQLQQPQQPLAQPQQPQQPFPQQQQPLIQPYLQQQMNPCKNCLLQQCNPVSLVSSLVSMILPR SDCQVMRQQCCQQLAQIPQQLQCAAIHGVVHSIIMQQEQQQQQGIQILRPLFQLVQGQGIIQPLTTAQLEVIRSLVLGNSPKHVHVFVPTECSTTKGTFAS IVADIGGQ

\begin{tabular}{c|c} 
Einkorn Storage Protein (ID ${ }^{\mathrm{a}}$ ) & Amino Acid Residues \\
$\alpha$-gliadin (B8XU27) & 309 \\
\hline
\end{tabular}

MKTFLIISLLAIVATTATTAVRVPVPOLOPQNPSLOQPQEQVPLVOOQOFPGOQQTFPPOQPYPQPQPFPAOQPYPOPQLFPQPQPFPPQLPYPQPQPFPPQ QPYPQPQTQHLQPQQPISQQQAQQQQQQQQQQQQQQQQQQQQQILQQILQQQQLIPCRDVIVLQQHNIAHESSQVLQQSSYQVLQQLCCQQLRQIPEQS RCQAINNVVHAIILHQQQQQQGQHQPSSQVSYQQPQQQYPSGQGSFQPSQQNPQAQGFVQPQHLPRLEEISNLALQTLPAMCNVYIPPYCSTTLRHLASS VPTEKRKI

Einkorn Storage Protein $\left(\mathrm{ID}^{\mathrm{a}}\right)$

Avenin like protein (A7XUQ1) Amino Acid Residues 284

MKVFILALLALAATTAIAQLETTCSQGFAQSQQQQQPAQROLLEOKKICAAFLOQQCSPLRMPFLOTQVEOLSSCOIVQYOCCOQLAOIPVPTRCHAIH NVEEAINQQQSQQQLQEVQQQAQHKTMRMLLENLSLMCNIYVPLQCQQQQQLGQQQQQQLQVQLTPCTTFLQPQCSPVTVPFPQIPADQPTSCQNVQ HQCCPQLSQIPEQFRCQAIHNVAEAIRQQQPQQQCQGMYQPQQPAQLESIRMSLQALRSMCSIYIPVQCPTPTGYKIPSVATYTGGAC

\begin{tabular}{c|c} 
Wheat Storage Protein $\left(\mathrm{ID}^{\mathrm{a}}\right)$ & Amino Acid Residues \\
HMW glutenin(P08489) & 838
\end{tabular}

\begin{tabular}{c|c} 
HMW glutenin(P08489) & 838 \\
\hline MAKRLVLFVAVVVALVALTVAEGEASEQLQCERELQELQERELKACQQVMDQQLRDISPECHPVVVSPVAGQYEQQIVVPKGGSFYPGETTPPQQLQ
\end{tabular} QRIFWGIPALLKRYYPSVTSPQQVSYYPGQASPQRPGQGQQPGQGQQSGQGQQGYYPTSPQQPGQWQQPEQGQPGYYPTSPQQPGQLQQPAQGQQPG QGQQGRQPGQGQPGYYPTSSQLPGQLQQPAQGQQGQQPGQGQQGQQPGQGQQPGQGQQGQQPGQGQQPGQGQQGQQLGQGQQGYYPTSLQQSG QGOPGYYPTSLOQLGQGOSGYYPTSPOQPGOGQQPGQLOQPAQGQOPEOGOQGOQPGOGOQGOQPGOGOQPGOGQPGYYPTSPOQSGOGOPGYYP TSSQQPTQSQQPGQGQQGQQVGQGQQAQQPGQGQQPGQGQPGYYPTSPLQSGQGQPGYYLTSPQQSGQGQQPGQLQQSAQGQKGQQPGQGQQPGQ GQQGQQPGQGQQGQQPGQGQPGYYPTSPQQSGQGQQPGQWQQPGQGQPGYYPTSPLQPGQGQPGYDPTSPQQPGQGQQPGQLQQPAQGQQGQQLA

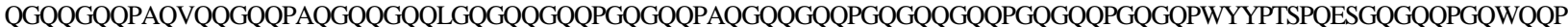
GQWQQPGQGQPGYYLTSPLQLGQGQQGYYPTSLQQPGQGQQPGQWQQSGQGQHGYYPTSPQLSGQGQRPGQWLQPGQGQQGYYPTSPQQSGQGQ QLGQWLQPGQGQQGYYPTSLQQTGQGQQSGQGQQGYYSSYHVSVEHQAASLKVAKAQQLAAQLPAMCRLEGGDALSASQ Wheat Storage Protein $\left(\mathrm{ID}^{\mathrm{b}}\right)$ \begin{tabular}{l|l} 
LMW glutenin (1329) & 388
\end{tabular}

MKTFLVFALLALAAASAVAQISQQQQPPPFSQQQQPPFSQQQQPPFSQQQQSPFSQQQQQPPFSQQQQPPFSQQPLISQQQQLPFSQQQQPQFSQQQQPPY SQQQQPPYSQQQQPPFSQQQQPPFSQQQQPSFSQQQQQPPFTQQQQPPFSQQSPISQQQQQQQQQQQQPFTQQQQPPFSQQPPISQQQQPPFSQQQQPPFS QQQQIPVIHPSVLQQLNPCKVFLQQQCIPVAMQRCLARSQMLQQSICHVMQRQCCQQLRQIPEQSRHESIRAIIYSIILQQQQQQQQQQQQQQQGQSIIQY QQQPPQQLGQCVSQPQQQLQQQLGQQPQQQQLAHGTFLQPHQIAQLEVMTSIALRTLPRMCSVNVPLYETTTSVPLGVGIGVGVY \begin{tabular}{|l|l} 
Wheat Storage Protein $\left(\mathrm{ID}^{\mathrm{b}}\right)$ & Amino Acid Residues
\end{tabular} $\omega$-gliadin (1418) 280

MKTFLIFVLLAMAMKIATAARELNPSNKELOSPQOSFSYOQQPFPQQPYPOQPYPSQQPYPSOQPFPTPQQQFPEQSOQPFTQPQQPTPIQPQQPFPQQPQ QPQQPFPQPQQPFPWQPQQPFPQTQQSFPLQPQQPFPQQPQQPFPQPQLPFPQQSEQIIPQQLQQPFPLQPQQPFPQQPQQPFPQPQQPIPVQPQQSFPQQSQ QSQQPFAQPQQLFPELQQPIPQQPQQPFPLQPQQPFPQQPQQPFPQQPQQSFPQQPQQPYPQQQPYGSSLTSIGGQ Wheat Storage Protein $\left(\mathrm{ID}^{\mathrm{b}}\right)$ Amino Acid Residues $\gamma$-gliadin (1317) 282

MNIQVDPSSQVPWPQQQPFPQPHQPFSQQPQQTFPQPQQTFPHQPQQQFSQPQQPQQQFIQPQQPFPQQPQQTYPQRPQQPFPQTQQPQQPFPQSQQPQQ PFPQPQQQFPQPQQPQQSFPQQQPSLIQQSLQQQLNPCKNFLLQQCKPVSLVSSLWSMILPRSDCQVMRQQCCQQLAQIPQQLQCAAIHSIVHSIIMQQEQ QEQRQGVQILVPLSQQQQVGQGTLVQGQGIIQPQQPAQLEVIRSLVLQTLATMCNVYVPPYCSTIRAPFASIVAGIGGQYR Wheat Storage Protein $\left(\mathrm{ID}^{\mathrm{b}}\right)$ $\alpha$-gliadin (1305) Amino Acid Residues 313

MKTFLILALVATTATTAVRVPVPQLQPKNPSQQQPQEQVPLVQQQQFPGQQQQFPPQQPYPQPQPFPSQQPYLQLQPFPQPQPFLPQLPYPQPQSFPPQQP YPQQRPKYLQPQQPISQQQAQQQQQQQQQQQQQQQQQILQQILQQQLIPCRDVVLQQHNIAHASSQVLQQSTYQLLQLCCQQLLQIPEQSRCQAIHN VVHAIIMHQQEQQQQLQQQQQQQLQQQQQQQQQQQQPSSQVSFQQPQQQYPSSQVSFQPSQLNPQAQGSVQPQQLPQFAEIRNLALQTLPAMCNVYIP PHCSTTIAPFGIFGTN

${ }^{a}$ The sequences of einkorn storage proteins were obtained from UniProtKB database, ${ }^{b}$ The sequences of wheat storage proteins were obtained from BIOPEP-UWM database, ${ }^{~}$ Amino acid nomenclature: C, cys; cysteine; H, his; histidine; I, ile; isoleucine; M, met; methionine; S, ser; serine; V, val; valine; A, ala; alanine; G, gly; glycine; L, leu; leucine; P, pro; proline; T, thr; threonine; F, phe; phenylalanine; R, arg; arginine; Y, tyr; tyrosine; W, trp; tryptophan; D, asp; aspartic acid; N,asn; asparagine; B, asx; either of D or N; E, glu; glutamic acid; Q, gin; glutamine; Z, glx; either of E or Q; K, lys; lysine; X, undetermined amino acid 
Table 2 Homology analysis of wheat and einkorn proteins

\begin{tabular}{|c|c|c|c|c|c|}
\hline \multicolumn{2}{|c|}{ Protein name and ID } & \multirow{2}{*}{ Identity (\%) } & \multirow{2}{*}{ Similarity $(\%)^{\mathrm{c}}$} & \multirow{2}{*}{ Gaps $(\%)$} & \multirow{2}{*}{ Scores } \\
\hline Wheat $^{\mathrm{a}}$ & Einkorn $^{\mathrm{b}}$ & & & & \\
\hline$\alpha$-gliadin (1305) & $\alpha$-gliadin (B8XU27) & 76.8 & 81.0 & 9.8 & 1251.0 \\
\hline$\gamma$-gliadin $(1317)$ & $\gamma$-gliadin (B8XU38) & 68.5 & 71.7 & 15.6 & 1059.0 \\
\hline$\omega$-gliadin $(1418)$ & $\omega$-gliadin (D6QY51) & 54.1 & 58.2 & 29.3 & 966.0 \\
\hline HMW glutenin (P08489) & HMW glutenin (A0A0M4FY26) & 71.5 & 73.2 & 15.8 & 3136.0 \\
\hline LMW glutenin (1329) & LMW glutenin (B8XU50) & 85.3 & 87.4 & 10.1 & 1663.5 \\
\hline
\end{tabular}

${ }^{a}$ Wheat Protein sequences from BIOPEP-UWM, ${ }^{b}$ Einkorn Protein sequences from UniProtKB, ${ }^{c}$ Sequence similarity analysis was made by EMBOSS Needle (EMBL-EBI), Parameters: Matrix (EBLOSUM62), Gap_penalty (10.0), Extend_penalty (0.5), The Identity: is the percentage of identical matches between the two sequences over the reported aligned region (including any gaps in the length), The Similarity: is the percentage of matches between the two sequences over the reported aligned region (including any gaps in the length).

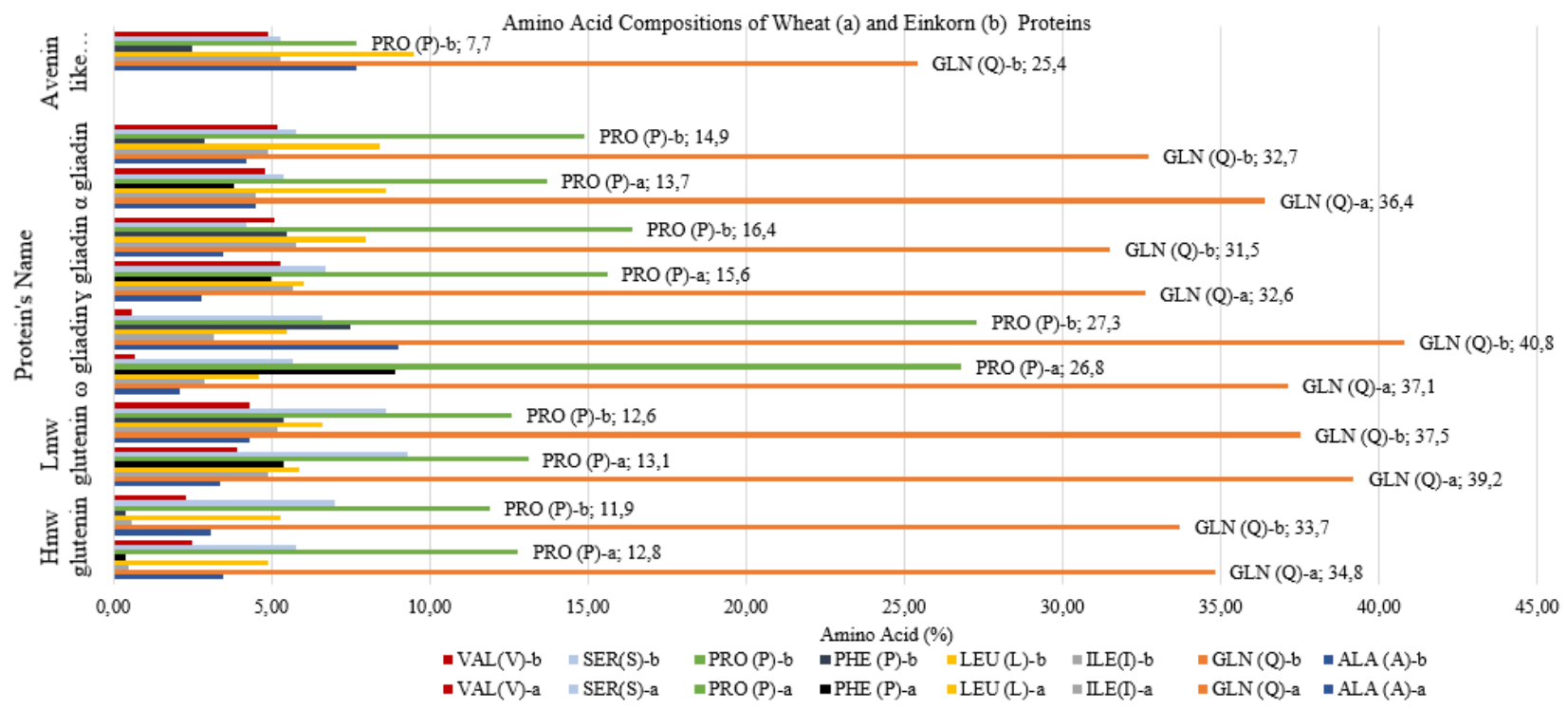

Figure 1 Theoretically calculated percentage of amino acids in the primary structure of wheat and einkorn storage proteins. (a) The percentage of other calculated amino acids for complete wheat protein sequences: $\mathrm{E}(1-7,5 \%), \mathrm{C}(0-3,17 \%), \mathrm{G}(1,1-5,6 \%), \mathrm{T}(2,3-3,2 \%)$, $\mathrm{Y}(1,4-$ 4,3\%), $\mathrm{R}(0,4-2,5) \mathrm{N}(0-2,2), \mathrm{H}(0-1,9), \mathrm{K}(0,5-1,1), \mathrm{M}(0,4-1,8 \%), \mathrm{D}(0-0,7), \mathrm{W}<1 \%$ (b) The percentage of other calculated amino acids for complete einkorn protein sequences: $\mathrm{E}(0-3,5 \%), \mathrm{C}(0,5-6,7 \%), \mathrm{G}(1,1-16,8 \%), \mathrm{T}(0,9-5,6 \%), \mathrm{Y}(0,3-5,9 \%), \mathrm{R}, \mathrm{N}, \mathrm{H}, \mathrm{K}, \mathrm{M}(0-3 \%), \mathrm{D}, \mathrm{W}<1 \%$

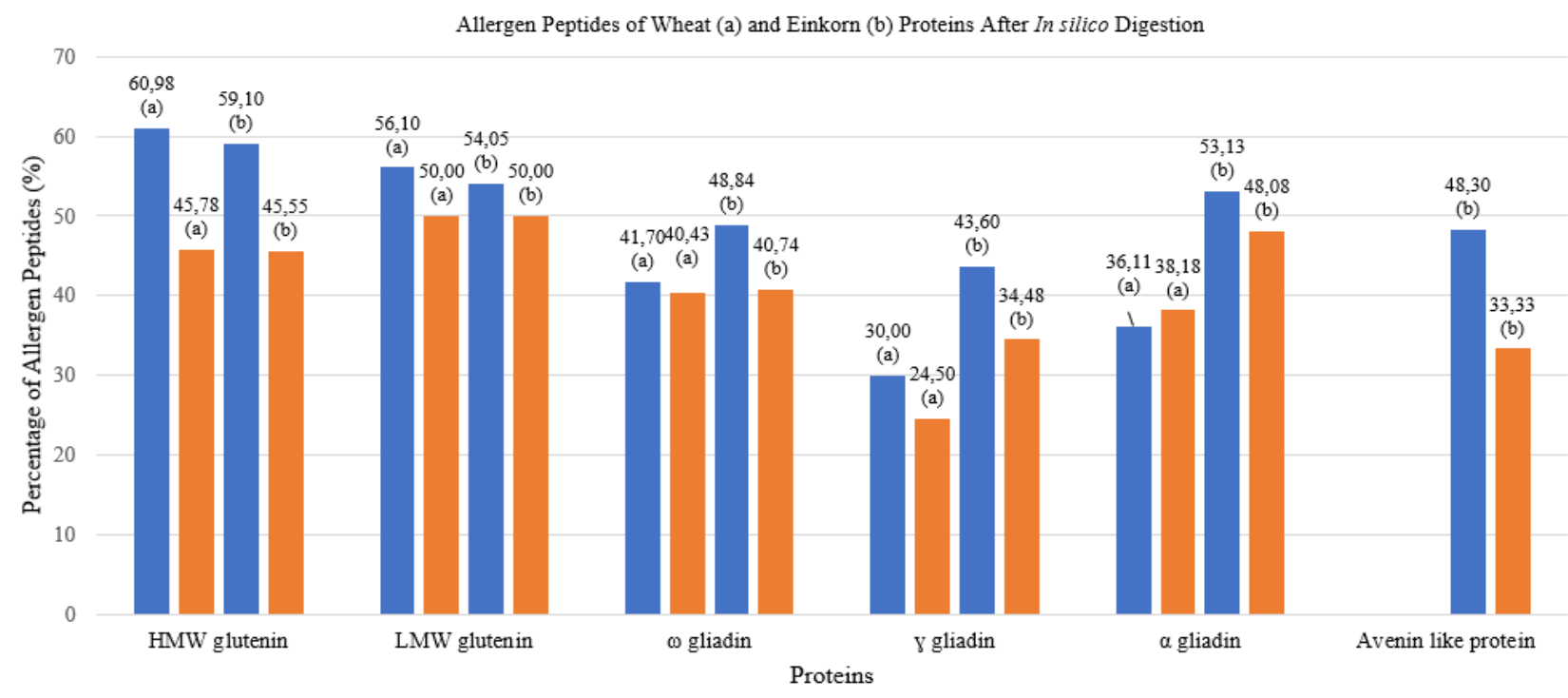

- Pepsin Digestion-a $\approx$ Pepsin+Trypsin+Chymotrypsin Digestion-a $₫$ Pepsin Digestion-b $\approx$ Pepsin+Trypsin+Chymotrypsin Digestion-b

Figure 2 Percentage of allergen peptides after wheat and einkorn protein digestion

Allergenicity predictions of all released peptides after in silico digestion showed that the HMW glutenin protein of wheat contains more allergen peptide $(60.98 \%)$ than other wheat and einkorn proteins after pepsin digestion (Figure 2). However, the occurrence of allergen peptides decreased to
$45.78 \%$ after intestinal digestion. Allergome database, which has been designed to supply information about allergenic molecules and sources, listed 101 completely or partially sequenced experimentally discovered Triticum aestivum allergens. Five of them were belonging to glutenin 
(HMW glutenin subunit and LMW glutenin subunit) and gliadin ( $\alpha$-gliadin, $\beta$-gliadin, $\gamma$-gliadin and $\omega$-5-gliadin) proteins. Among the einkorn proteins, the release of allergen peptides after pepsin digestion of HMW glutenin was higher than those of other proteins. The important finding was that the increase in the release of allergen peptides after gastrointestinal digestion (gastric + intestinal) of $\alpha$-gliadin than that of gastric digestion. On the contrary, the release of allergen peptides from other proteins decreased after gastrointestinal digestion regarding gastric digestion. Alergome database listed 4 completely or partially sequenced experimentally discovered Triticum monococcum allergens. None of them were belonging to storage proteins of Triticum monococcum.

To the best of our knowledge, studies related to allergenicity prediction of peptides using in silico tools are scarce. Bioactive properties of oat protein hydrolysate using AllerTOP and ACE inhibitory activity of rice bran proteins using both AllerTop and AllergenFP programs were reported (Bleakley et al., 2017; Pooja et al., 2017).

Examination of toxicity of all peptides after gastric and gastrointestinal digestion showed that peptides with PRSDCQVMRQQCCQLL sequence released after gastric digestion of einkorn $\gamma$-gliadin and PAMCNVYIPPYCSTTL sequence released after gastric digestion of einkorn $\alpha$ gliadin could have toxic effects. Two peptides sequences, SSCQIVQYQCCQQL and PQIPADQPTSCQNVQHQCCPQL, which were released following gastric digestion of einkorn avenin like protein were found to be toxic and allergen. However, intestinal digestion of einkorn $\gamma$-gliadin, $\alpha$ gliadin and avenin like protein caused the disappearance of toxic peptides. In the study of Šuligoj et al., 2013 toxicity of einkorn wheat was found to be lower than that of modern wheat. However, researchers stated that the consumption of einkorn wheat could be harmful for celiac patients so einkorn wheat consumption by celiac patients was not recommended (Šuligoj et al., 2013). Toxic peptide sequences were determined following gastric digestion of common wheat LMW glutenin, $\alpha$-gliadin, and $\gamma$-gliadin. These sequences were (QQSICHVMQRQCCQQL), (PAMCNVYIPPHCSTTIAPF) and (PRSDCQVMRQQCCQQLATMCNVYVPPYCSTIRAPF) for LMW glutenin, $\alpha$ gliadin, and $\mathrm{\gamma}$-gliadin, respectively. Similar to einkorn proteins these sequences disappeared after gastrointestinal digestion.

In the case of bioactive peptides, no toxicity and allergenicity were observed for both kinds of wheat after gastric and gastrointestinal digestion.

\section{Bioactivity Profiles of Digested Proteins}

In silico gastric and gastrointestinal digestion of modern wheat and einkorn wheat showed that DPP IV inhibitory, ACE inhibitory, antioxidative, stimulating vasoactive substance release, glucose uptake stimulating, antiamnestic, celiac toxic, renin inhibitory, and DPP III inhibitory peptides were released (Table 3 ).

Bioactive peptides having DPP IV inhibitory activity and glucose uptake stimulating effect peptide (VL) from einkorn wheat HMW glutenin after pepsin hydrolysis and bioactive peptides having DPP IV inhibitory activity (QL) and VL from modern wheat HMW glutenin were observed. However, the activity scores of VL and QL were 0.126 and 0.292 respectively, which indicated low activity. Digestion of wheat HMW glutenin with gastrointestinal enzymes caused the generation of five bioactive peptides. Some of them have ACE inhibitory activity (IF) and DPP IV and ACE inhibitory activity (GY) with high activity scores (0.949 and 0.741 respectively) (Table 3 ). In the case of einkorn HMW glutenin variety of bioactive peptides was high and among these peptides, dipeptides QW (0.928) with DPP IV inhibitory activity and GY (0.741) with DPP IV and ACE inhibitory activities displayed higher activity scores. This difference in bioactive peptide formation could be explained with the differences in the structure of einkorn and wheat HMW glutenin (as shown in Table 2). Two bioactive peptides with identical sequences were obtained after pepsin hydrolysis of LMW glutenin proteins of both kinds of wheat. In addition, dipeptide PF (0.993) released after pepsin hydrolysis of wheat LMW glutenin. However, most of the bioactive peptides occurred after gastrointestinal digestion of both wheat LMW glutenin proteins have same bioactive peptides. The nonidentical bioactive peptides found in modern wheat were TL, PF, $\mathrm{PR}, \mathrm{AH}$ and VPL and found in einkorn wheat was TH. The number of peptides having different activities was higher in modern wheat than those of einkorn wheat after gastric and gastrointestinal digestion of their $\omega$-gliadin proteins. The similar tendency was obtained for $\mathrm{\gamma}$ - gliadin proteins of two kinds of wheats. However, celiac toxic pentadecapeptide sequence (VQGQGIIQPQQPAQL) was determined in wheat $\mathrm{\gamma}$-gliadin after gastric and gastrointestinal digestion. In silico digestion of einkorn $\alpha$ gliadin generated five bioactive peptides while wheat $\alpha$ gliadin generated six bioactive peptides. Similar to wheat $\gamma$-gliadin, in silico digestion of wheat $\alpha$-gliadin caused the release of celiac toxic dodecapeptide (PSQQQPQEQVPL). In silico gastrointestinal digestion of avenin like protein caused the release of nine dipeptides having DPP IV inhibitory, ACE inhibitory and DPP III inhibitory, antioxidative, glucose uptake stimulating activities and one tripeptide having DPP IV inhibitory, stimulating vasoactive substance release and antiamnestic activities.

In silico bioactivity analysis showed that most of the released peptides displayed DPP IV and ACE inhibitory activities. DPP IV is a serine protease that mediates the inactivation of the glucose-dependent insulinotropic polypeptide (GIP) and glucagon-like peptide-1 (GLP-1), which are incretin hormones that stimulate insulin secretion. DPP IV inhibitor or gliptins enhance incretin levels, inhibit glucagon release, increase insulin secretions, and decrease blood glucose levels (Bleakley et al., 2017). For these reasons, they have been considered good functional agents to treat diabetes mellitus type 2 (Bleakley et al., 2017; Hatanaka et al., 2012; Pratley, 2008; Udenigwe et al., 2013). Angiotensin-I-converting enzyme (ACE-I, EC 3.4.15.1.) has a crucial role in hypertension control, type-2 diabetes, and other metabolic disorders (Li et al., 2016; Zheng et al., 2017). Inhibition of ACE-I can cause regulation of blood pressure so ACE-I inhibitors can be effective for the treatment of hypertension (Ondetti and Cushman, 1982). In silico gastrointestinal digestion showed that bioactivities of the peptides released from modern wheat and einkorn were identical. However, hydrolysis degree of proteins, frequency of release of fragments from intact proteins and relative frequency of release of fragments from intact proteins were different (Table 4). 
Table 3. Einkorn and wheat proteins derived bioactive peptides and their PeptideRanker scores

\begin{tabular}{|c|c|c|c|}
\hline Einkorn & \multirow{2}{*}{$\begin{array}{l}\text { Type of } \\
\text { peptide }^{c}\end{array}$} & $\begin{array}{l}\text { Bioactive peptides after } \\
\text { pepsin digestion }^{\mathrm{b}}\end{array}$ & $\begin{array}{l}\text { Bioactive peptides after pepsin,trypsin and } \\
\text { chymotrypsin digestion }^{\mathrm{b}}\end{array}$ \\
\hline $\begin{array}{l}\text { Protein }(\mathrm{Mw}, \mathrm{Da})^{\mathrm{a}} \\
-(\mathrm{pI})^{\mathrm{a}}\end{array}$ & & Sequences & Sequences (Peptide Ranker Score) \\
\hline $\begin{array}{l}\text { HMW glutenin } \\
(87954.30)-(8.08)\end{array}$ & $\begin{array}{l}\text { mono } \\
\text { bi } \\
\text { tri }\end{array}$ & $\mathrm{VL}^{1,5}(0.126)$ & $\begin{array}{c}\mathrm{QK}^{2}(0.062), \mathrm{EL}^{3}(0.073), \mathrm{SL}^{1}(0.330), \mathrm{QL}^{1}(0.292) \\
\mathrm{QW}^{1}(0.928), \mathrm{QY}^{1}(0.233), \mathrm{TK}^{1}(0.033) \\
\mathrm{GY}^{1,2}(0.741), \mathrm{VL}^{1,5}(0.126) \\
-\end{array}$ \\
\hline $\begin{array}{l}\text { LMW glutenin } \\
(40007.93)-(8.70)\end{array}$ & $\begin{array}{l}\text { mono } \\
\text { bi } \\
\text { tri } \\
\text { tetra }\end{array}$ & $\begin{array}{l}\mathrm{AL}^{1}(0.438) \\
\mathrm{VF}^{1.2}(0.815) \\
-\end{array}$ & $\begin{array}{c}\mathrm{AR}^{2}(0.394), \mathrm{AL}^{1}(0.438), \mathrm{TH}^{1}(0.076), \mathrm{VM}^{1}(0.329) \\
\mathrm{VF}^{1,2}(0.815) \\
- \\
\mathrm{TF}^{1,2,8,9}(0.827)\end{array}$ \\
\hline $\begin{array}{l}\omega \text {-gliadin } \\
(40492.95)-(7.14)\end{array}$ & $\begin{array}{l}\text { mono } \\
\text { Bi } \\
\text { tri } \\
\text { tetra }\end{array}$ & $\begin{array}{c}\mathrm{PL}^{1,2}(0.811), \mathrm{PF}^{1,9}(0.993) \\
- \\
-\end{array}$ & $\begin{array}{c}\mathrm{AR}^{2}(0.394), \mathrm{EL}^{3}(0.073), \mathrm{QL}^{1}(0.292), \mathrm{SW}^{1}(0.934) \\
\mathrm{PL}^{1,2}(0.811), \mathrm{PH}^{1,2}(0.541), \mathrm{PW}^{1,3}(0.993), \mathrm{PF}^{1,9}(0.993) \\
- \\
-\end{array}$ \\
\hline $\begin{array}{l}\gamma \text {-gliadin } \\
(35360.43)-(8.49)\end{array}$ & $\begin{array}{l}\text { mono } \\
\text { bi } \\
\text { tri } \\
\text { tetra }\end{array}$ & $\begin{array}{c}\mathrm{QL}^{1}(0.292) \\
\mathrm{VL}^{1,5}(0.126), \mathrm{PF}^{1,9}(0.993) \\
\mathrm{IL}^{1,2,5}(0.393) \\
-\end{array}$ & $\begin{array}{c}\mathrm{SL}^{1}(0.330), \mathrm{QL}^{1}(0.292), \mathrm{TL}^{1}(0.144), \mathrm{VH}^{1}(0.070) \\
\mathrm{VF}^{1,2}(0.815), \mathrm{PL}^{1,2}(0.811), \\
\mathrm{PH}^{1,2}(0.541), \mathrm{VL}^{1,5}(0.126), \mathrm{PR}^{2,9}(0.788), \mathrm{PF}^{1,9}(0.993) \\
\mathrm{IL}^{1,2,5}(0.393) \\
-\end{array}$ \\
\hline $\begin{array}{l}\alpha \text {-gliadin } \\
(35478.95)-(8.57)\end{array}$ & $\begin{array}{l}\text { mono } \\
\text { bi } \\
\text { tri } \\
\text { tetra }\end{array}$ & $\begin{array}{c}\mathrm{RHL}^{3}(0.410), \mathrm{AL}^{1}(0.438) \\
- \\
- \\
-\end{array}$ & $\begin{array}{c}\mathrm{AL}^{1}(0.438), \mathrm{PY}^{1}(0.737) \\
\operatorname{PR}^{2,9}(0.788) \\
\mathrm{TF}^{1,2,8,9}(0.827), \mathrm{VY}^{1,2,3,9}(0.100)\end{array}$ \\
\hline $\begin{array}{l}\text { Avenin like protein } \\
(32035.86)-(7.81)\end{array}$ & $\begin{array}{l}\text { mono } \\
\text { bi } \\
\text { tri }\end{array}$ & $\begin{array}{c}\mathrm{AL}^{1}(0.438), \mathrm{SL}(0.330) \\
- \\
\mathrm{IL}^{1,2,5}(0.393)\end{array}$ & $\begin{array}{c}\mathrm{AL}^{1}(0.438), \mathrm{SL}^{1}(0.330), \mathrm{QL}^{1}(0.292), \mathrm{TM}^{1}(0.356) \\
\mathrm{SM}^{9}(0.628) \\
\mathrm{IY}^{2,3}(0.315), \mathrm{VF}^{1,2}(0.815), \mathrm{PF}^{1,9}(0.993) \\
\mathrm{IL}^{1,2,5}(0.393), \mathrm{VPL}^{1,4,6}\end{array}$ \\
\hline Wheat & Type of & $\begin{array}{l}\text { Bioactive peptides after } \\
\text { pepsin digestion }\end{array}$ & $\begin{array}{c}\text { Bioactive peptides after pepsin,trypsin and } \\
\text { chymotrypsin digestion }^{\mathrm{b}}\end{array}$ \\
\hline $\begin{array}{l}\text { Protein }(\mathrm{Mw}, \mathrm{Da})^{\mathrm{a}} \\
-(\mathrm{pI})^{\mathrm{a}}\end{array}$ & peptide $^{c}$ & Sequences & Sequences (Peptide Ranker Score) \\
\hline $\begin{array}{l}\text { HMW glutenin } \\
(89173.42)-(5.83)\end{array}$ & $\begin{array}{l}\text { Mono } \\
\text { bi } \\
\text { tri }\end{array}$ & $\begin{array}{l}\mathrm{QL}^{1}(0.292) \\
\mathrm{VL}^{1,5}(0.126) \\
-\end{array}$ & $\begin{array}{c}\mathrm{EL}^{3}(0.073), \mathrm{QL}^{1}(0.292), \mathrm{IF}^{2}(0.949) \\
\mathrm{VL}^{1,5}(0.126), \mathrm{GY}^{1,2}(0.741) \\
-\end{array}$ \\
\hline $\begin{array}{l}\text { LMW glutenin } \\
(44729.97)-(9.04)\end{array}$ & $\begin{array}{l}\text { mono } \\
\text { bi } \\
\text { tri } \\
\text { tetra }\end{array}$ & $\begin{array}{c}\mathrm{AL}^{1}(0.438) \\
\mathrm{VF}^{1,2}(0.815) \mathrm{PF}^{1,9}(0.993)\end{array}$ & $\begin{array}{c}\mathrm{AR}^{2}(0.394), \mathrm{AL}^{1}(0.438), \mathrm{TL}^{1}(0.144), \mathrm{VM}^{1}(0.329) \\
\mathrm{VF}^{1,2}(0.815), \mathrm{PF}^{1,9}(0.993), \mathrm{PR}^{2,9}(0.788) \\
\operatorname{VPL}^{1,4,6}(0,368), \mathrm{AH}^{1,2,3}(0.210) \\
\mathrm{TF}^{1,2,8,9}(0.827)\end{array}$ \\
\hline $\begin{array}{l}\omega \text {-gliadin } \\
(32553.35)-(5.06)\end{array}$ & $\begin{array}{l}\text { mono } \\
\text { bi } \\
\text { tri } \\
\text { tetra }\end{array}$ & $\begin{array}{c}\mathrm{IF}^{2}(0.949), \mathrm{PEL}^{3}(0.235) \\
\mathrm{PF}^{1,9}(0.993), \mathrm{VL}^{1,5}(0.126) \\
\mathrm{PL}^{1,2}(0.811)\end{array}$ & $\begin{array}{c}\mathrm{IF}^{2}(0.949), \mathrm{EL}^{3}(0.073), \mathrm{PEL}^{3}(0.235) \\
\mathrm{PL}^{1,2}(0.811), \mathrm{SY}^{1,2}(0.262), \mathrm{PW}^{1,3}(0.993) \\
\mathrm{VL}^{1,5}(0.126), \mathrm{PF}^{1,9}(0.993) \\
- \\
\mathrm{TF}^{1,2,8,9}(0.827)\end{array}$ \\
\hline $\begin{array}{l}\gamma \text {-gliadin } \\
(32327.64)-(8.71)\end{array}$ & $\begin{array}{l}\text { mono } \\
\text { bi } \\
\text { tri } \\
\text { tetra }\end{array}$ & $\begin{array}{l}\text { VQGQGIIQPQQPAQL }{ }^{7} \\
\text { VL }^{1,5}(0.126) \\
\text { VPL }^{1,4,6}(0,368)\end{array}$ & $\begin{array}{c}\mathrm{PQR}^{2}(0.488), \mathrm{PR}^{2}(0.788), \mathrm{SL}^{1}(0.330), \mathrm{SM}^{9}(0.628), \\
\mathrm{VQGQGIIQPQQPAQL}^{7}(0.232) \\
\mathrm{PH}^{1,2}(0.541), \mathrm{VL}^{1,5}(0.126) \\
\mathrm{IL}^{1,2,5}(0.393), \mathrm{VPL}^{1,4,6}(0,368) \\
\mathrm{VY}^{1,2,3,9}(0.100)\end{array}$ \\
\hline $\begin{array}{l}\alpha \text {-gliadin } \\
(36144.67)-(8.58)\end{array}$ & $\begin{array}{l}\text { mono } \\
\text { bi } \\
\text { tri } \\
\text { tetra }\end{array}$ & $\begin{array}{c}\mathrm{AL}^{1}(0.438), \mathrm{QL}^{1}(0.292) \\
- \\
\mathrm{IL}^{1,2,5}(0.393)\end{array}$ & $\begin{array}{c}\mathrm{IY}^{2}(0.315), \mathrm{AL}^{1}(0.438) \\
\text { PSQQQPQEQVPL }(0.332), \mathrm{PK}^{1}(0.326) \\
\operatorname{PY}^{1}(0.737) \mathrm{QL}^{1}(0.292) \\
- \\
\mathrm{IL}^{1,2,5}(0.393) \\
\mathrm{TF}^{1,2,8,9}(0.827), \mathrm{VY}^{1,2,3,9}(0.100)\end{array}$ \\
\hline
\end{tabular}

${ }^{1}$ DPP IV inhibitor; ${ }^{2} \mathrm{ACE}$ inhibitor; ${ }^{3}$ Antioxidative; ${ }^{4}$ Stımulatıng vasoactıve substance release; ${ }^{5}$ Glucose uptake stimulating; $;{ }^{6}$ Antiamnestic, ${ }^{7} \mathrm{Celiac}$ toxic ,${ }^{8}$ renin inhibitor, ${ }^{9} \mathrm{DPP}$ III Inhibitor, ${ }^{\mathrm{a}}$ Molecular weight and isoelectric points data is obtained from ProtParam Program ${ }^{\mathrm{b}} \mathrm{BIOPEP}-\mathrm{UWM}$ Database, c The classification in the peptide type column indicates the number of bioactive properties of the peptides. mono: the peptide only has one bioactivity. (e.g. ACE inhibitor). bi: the peptide has two bioactivities. (e.g. ACE and DPP IV inhibitor). tri: the peptide has three bioactivities. tetra: the peptide has four bioactivities. 
Table 4. DHt, $\mathrm{A}_{\mathrm{E}}$ and $\mathrm{W}$ values of einkorn and wheat derived bioactive peptides

\begin{tabular}{|c|c|c|c|c|c|c|c|}
\hline \multicolumn{8}{|c|}{ Einkorn Proteins } \\
\hline \multicolumn{4}{|c|}{ After Pepsin Digestion } & \multicolumn{4}{|c|}{ After pepsin+trypsin+chymotrypsin digetion } \\
\hline Activity & $\mathrm{DHt} \%$ & $\mathrm{AE}$ & $\mathrm{W}$ & Activity & DHt $\%$ & $\mathrm{AE}$ & $\mathrm{W}$ \\
\hline \multicolumn{8}{|c|}{ HMW glutenin } \\
\hline GUSP & \multirow{4}{*}{5.693} & 0.0012 & 0.1622 & ACE inhibitor & \multirow{4}{*}{17.0762} & 0.0025 & 0.0046 \\
\hline \multirow[t]{3}{*}{ DPP IV inhibitor } & & 0.0012 & \multirow[t]{3}{*}{0.0017} & Antioxidative & & 0.0012 & 0.0263 \\
\hline & & & & GUSP & & 0.0012 & 0.1622 \\
\hline & & & & DPP IV inhibitor & & 0.0099 & 0.0142 \\
\hline & & & LMW & lutenin & & & \\
\hline ACE Inhibitor & 120690 & 0.0029 & 0.0101 & ACE inhibitor & & 0.0143 & 0.0499 \\
\hline DPP IV inhibitor & 12.0090 & 0.0086 & 0.0114 & DPP IV inhibitor & 195402 & 0.0201 & 0.0266 \\
\hline & & & & Hypotensive & 19,3402 & 0.0029 & 0.1443 \\
\hline & & & & DPP III inhibitor & & 0.0029 & 0.0337 \\
\hline & & & $\omega-\mathrm{g}$ & $\operatorname{adin}$ & & & \\
\hline ACE inhibitor & & 0.0115 & 0.0288 & ACE inhibitor & & 0.0172 & 0.0431 \\
\hline DPP IV inhibitor & 12,9683 & 0.0144 & 0.0163 & Antioxidative & & 0.0057 & 0.2836 \\
\hline DPP III inhibitor & & 0.0029 & 0.0481 & DPP IV inhibitor & $1 /, 5 / 93$ & 0.0259 & 0.0294 \\
\hline & & & & DPP III inhibitor & & 0.0029 & 0.0481 \\
\hline & & & $\gamma-\mathrm{g}$ & $\operatorname{adin}$ & & & \\
\hline ACE inhibitor & & 0.0032 & 0.0088 & ACE inhibitor & & 0.0225 & 0.0619 \\
\hline DPP IV inhibitor & & 0.0129 & 0.0159 & DPP IV inhibitor & & 0.0386 & 0.0474 \\
\hline GUSP & 15,3484 & 0.0064 & 0.1245 & GUSP & 22,2581 & 0.0096 & 0.1868 \\
\hline DPP III inhibitor & & 0.0032 & 0.0474 & DPP III inhibitor & & 0.0064 & 0.0948 \\
\hline & & & $\alpha-g$ & $\operatorname{adin}$ & & & \\
\hline Antioxidative & & 0.0032 & 0.0760 & ACE inhibitor & & 0.0097 & 0.0263 \\
\hline DPP IV inhibitor & 11,0390 & 0.0032 & 0.0041 & DPP IV inhibitor & & 0.0129 & 0.0163 \\
\hline & & & & Antioxidative & 22,7273 & 0.0032 & 0.0760 \\
\hline & & & & Hypotensive & & 0.0032 & 0.1649 \\
\hline & & & & DPP III inhibitor & & 0.0097 & 0.1499 \\
\hline & & & Avenin 1 & e protein & & & \\
\hline ACE inhibitor & & 0.0035 & 0.0116 & ACE inhibitor & & 0.0106 & 0.0350 \\
\hline DPP IV inhibitor & 12,0141 & 0.0141 & 0.0209 & DPP IV inhibitor & & 0.0352 & 0.0521 \\
\hline GUSP & & 0.0035 & 0.1423 & Antioxidative & & 0.0035 & 0.1659 \\
\hline & & & & Stimulating & 25,4417 & 0.0070 & 0.2846 \\
\hline & & & & DPP III inhibitor & & 0.0070 & 0.0864 \\
\hline & & & & Antiamnestic & & 0.0035 & 1.0000 \\
\hline & & & Wheat & roteins & & & \\
\hline & Digestion & & & After pe & $1+$ chymot & in digetic & \\
\hline Activity & $\mathrm{DHt} \%$ & $\mathrm{AE}$ & $\mathrm{W}$ & Activity & DHt $\%$ & $\mathrm{AE}$ & $\mathrm{W}$ \\
\hline & & & HMW & lutenin & & & \\
\hline Stimulating & 52443 & 0.0012 & 0.1690 & ACE inhibitor & & 0.0024 & 0.0043 \\
\hline DPP IV inhibitor & 5.2443 & 0.0024 & 0.0034 & Antioxidative & 146254 & 0.0024 & 0.0518 \\
\hline & & & & Stimulating & 14,0254 & 0.0012 & 0.1690 \\
\hline & & & & DPP IV inhibitor & & 0.0036 & 0.0051 \\
\hline & & & LMW & lutenin & & & \\
\hline ACE inhibitor & & 0.0026 & 0.0097 & ACE inhibitor & & 0.0155 & 0.0578 \\
\hline DPP IV inhibitor & 11.3695 & 0.0103 & 0.0136 & DPP IV inhibitor & & 0.0258 & 0.0342 \\
\hline DPP III inhibitor & & 0.0026 & 0.0315 & DPP III inhibitor & & 0.0077 & 0.0933 \\
\hline & & & & Antioxidative & 18.6047 & 0.0026 & 0.1121 \\
\hline & & & & Antiamnestic & & 0.0026 & 0.5000 \\
\hline & & & & Stimulating & & 0.0026 & 0.1008 \\
\hline & & & & Hypotensive & & 0.0026 & 0.1008 \\
\hline & & & $\omega-\mathrm{g}$ & $\operatorname{adin}$ & & & \\
\hline ACE inhibitor & & 0.0143 & 0.0348 & ACE inhibitor & & 0.0214 & 0.0521 \\
\hline DPP IV inhibitor & & 0.0179 & 0.0202 & Antioxidative & & 0.0143 & 0.5000 \\
\hline Antioxidative & 13.6201 & 0.0036 & 0.1259 & DPP IV inhibitor & 18 & 0.0286 & 0.0323 \\
\hline Stimulating & & 0.0036 & 0.2011 & Stimulating & 19,3348 & 0.0036 & 0.2011 \\
\hline DPP III inhibitor & & 0.0036 & 0.0420 & Hypotensive & & 0.0036 & 0.1440 \\
\hline & & & & DPP III inhibitor & & 0.0071 & 0.0828 \\
\hline$\gamma$-gliadin & & & & & & & \\
\hline Antiamnestic & 11.0320 & 0.0035 & 1.000 & ACE inhibitor & & 0.0177 & 0.0504 \\
\hline DPP IV inhibitor & & 0.0071 & 0.0088 & DPP IV inhibitor & & 0.0213 & 0.0265 \\
\hline Stimulating & & 0.0071 & 0.1431 & Stimulating & & 0.0106 & 0.2137 \\
\hline Celiac toxic & & 0.0035 & 0.0759 & DPP III inhibitor & 20.6406 & 0.0106 & 0.1495 \\
\hline & & & & Antioxidative & & 0.0035 & 0.0759 \\
\hline & & & & Celiac toxic & & 0.0035 & 0.0759 \\
\hline & & & & Antiamnestic & & 0.0035 & 1.0000 \\
\hline & & & $\alpha-g$ & $\operatorname{adin}$ & & & \\
\hline ACE inhibitor & & 0.0032 & 0.0771 & ACE inhibitor & & 0.0096 & 0.0281 \\
\hline DPP IV inhibitor & 12.5000 & 0.0128 & 0.0156 & DPP IV inhibitor & & 0.0288 & 0.0352 \\
\hline Stimulating & & 0.0032 & 0.0094 & Antioxidative & & 0.0032 & 0.1003 \\
\hline GUSP: Glucose uptake s & & & & Celiac toxic & 22,4359 & 0.0032 & 0.0358 \\
\hline & & & & Stimulating & & 0.0032 & 0.0771 \\
\hline & & & & Hypotensive & & 0.0032 & 0.1250 \\
\hline & & & & DPP III inhibitor & & 0.0064 & 0.1179 \\
\hline
\end{tabular}


Table 5. Sequences of possible bioactive peptides derived einkorn and wheat proteins according to PeptideRanker

\begin{tabular}{|c|c|c|c|c|c|}
\hline \multicolumn{6}{|c|}{ Einkorn proteins } \\
\hline \multicolumn{3}{|c|}{ After pepsin digestion } & \multicolumn{3}{|c|}{ After pepsin+trypsin+ chymotrypsin digestion } \\
\hline Sequence & Activity & Allergenicity & Sequence & Activity & Allergenicity \\
\hline \multicolumn{6}{|c|}{ HMW glutenin } \\
\hline PAMCRL & 0.898 & P.A. & GQW & 0.935 & P.N.A. \\
\hline WGIPAL & 0.885 & P.A. & GGSF & 0.908 & P.A. \\
\hline \multirow[t]{3}{*}{ RYYPTF } & 0.825 & P.A. & $\mathrm{CR}$ & 0.865 & P.N.A. \\
\hline & & & PTF & 0.850 & P.N.A. \\
\hline & & & PAM & 0.835 & P.A. \\
\hline \multicolumn{6}{|c|}{ LMW glutenin } \\
\hline GAF & 0.955 & P.N.A. & GAF & 0.955 & P.N.A. \\
\hline \multicolumn{6}{|c|}{$\alpha$-gliadin } \\
\hline PQPQPF & 0.920 & P.A. & PQPQPF & 0.920 & P.A. \\
\hline PYPQPQPF & 0.898 & P.N.A. & PAM & 0.835 & P.A. \\
\hline PPQQPYPQPQPF & 0.822 & P.A. & IPCR & 0.830 & P.N.A. \\
\hline PRL & 0.806 & P.N.A. & IPPY & 0.809 & P.N.A. \\
\hline \multicolumn{6}{|c|}{$\gamma$-gliadin } \\
\hline QQPF & 0.874 & P.A. & QQPF & 0.874 & P.A. \\
\hline QQQMNPCKNCL & 0.806 & P.N.A. & $\mathrm{CL}$ & 0.880 & P.N.A. \\
\hline & & & GTF & 0.849 & P.N.A. \\
\hline \multicolumn{6}{|c|}{$\omega$-gliadin } \\
\hline PWQPQQPF & 0.915 & P.N.A. & PQPQPF & 0.920 & P.A. \\
\hline QQPF & 0.874 & P.A. & QQPF & 0.874 & P.A. \\
\hline PQPQQPF & 0.838 & P.A. & PQPQQPF & 0.838 & P.A. \\
\hline QPQQPF & 0.812 & P.N.A. & QPQQPF & 0.812 & P.N.A. \\
\hline \multicolumn{6}{|c|}{ Avenin like protein } \\
\hline RMPF & 0.977 & P.A. & CAAF & 0.862 & P.N.A. \\
\hline CAAF & 0.862 & P.N.A. & QCCPQL & 0.830 & P.A. \\
\hline RSMCSIYIPVQCPTP & & & & & \\
\hline TGYKIPSVATYTGGC & 0.809 & P.A. & & & \\
\hline \multicolumn{6}{|c|}{ Wheat proteins } \\
\hline \multicolumn{3}{|c|}{ After pepsin digestion } & \multicolumn{3}{|c|}{ After pepsin+trypsin+ chymotrypsin digestion } \\
\hline Sequence & Activity & Allergenicity & Sequence & Activity & Allergenicity \\
\hline \multicolumn{6}{|c|}{ HMW glutenin } \\
\hline GQWL & 0.920 & P.N.A. & GGSF & 0.908 & P.A. \\
\hline PAMCRL & 0.898 & P.A & GQW & 0.935 & P.N.A \\
\hline \multirow[t]{3}{*}{ WGIPAL } & 0.885 & P.A. & PGQW & 0.929 & P.N.A. \\
\hline & & & $\mathrm{CR}$ & 0.865 & P.N.A. \\
\hline & & & PAM & 0.835 & P.A. \\
\hline \multicolumn{6}{|c|}{ LMW glutenin } \\
\hline QQOCIPVAMQRCL & 0.845 & P.N.A. & CL & 0.880 & P.N.A. \\
\hline & & & GTF & 0.849 & P.N.A. \\
\hline \multicolumn{6}{|c|}{$\alpha$-gliadin } \\
\hline QPF & 0.955 & P.N.A. & QPF & 0.955 & P.N.A. \\
\hline PQF & 0.935 & P.A. & GIF & 0.952 & P.N.A. \\
\hline POPOPF & 0.920 & P.A. & PQF & 0.935 & P.A. \\
\hline PPQQPYPQPQPF & 0.822 & P.A. & PPQQPY & 0.920 & P.N.A. \\
\hline & & & PQPQPF & 0.920 & P.A. \\
\hline & & & PAM & 0.835 & P.A. \\
\hline & & & IPCR & 0.830 & P.N.A. \\
\hline & & & adin & & \\
\hline WSMIL & 0.916 & P.N.A. & $\mathrm{QPF}$ & 0.955 & P.N.A. \\
\hline PQPHQPF & 0.865 & P.A. & PQQPF & 0.879 & P.N.A. \\
\hline NPCKNF & 0.817 & P.N.A. & & & \\
\hline & & & $\operatorname{adin}$ & & \\
\hline PWQPQQPF & 0.915 & P.N.A. & QPF & 0.955 & P.N.A. \\
\hline QQPF & 0.874 & P.A. & PQPQQPF & 0.838 & P.A. \\
\hline PQPQQPF & 0.838 & P.A. & QPQQPF & 0.812 & P.N.A. \\
\hline QPQQPF & 0.812 & P.N.A. & PSQQPF & 0.800 & P.A. \\
\hline
\end{tabular}

P.A. MEANS "Probable Allergen" and P.N.A. means "Probable Non Allergen" according to AllergenFP.

Hydrolysis degree of all proteins after pepsin hydrolysis was lower than those of pepsin+trypsin+chymotrypsin hydrolysis. This value for HMW glutenin of wheat and einkorn obtained from pepsin hydrolysis was $5.244 \%$ and $5.693 \%$ respectively. The highest DHt after pepsin hydrolysis was obtained for einkorn $\gamma$-gliadin $(13.548 \%)$ and wheat $\omega$-gliadin $(13.620 \%)$. After gastrointestinal digestion DHt values were $22,436 \%$ and $25.442 \%$ for wheat $\alpha$-gliadin and einkorn avenin like protein, respectively. The highest and the lowest $A_{E}$ values after pepsin hydrolysis were obtained for wheat $\omega$-gliadin as 0.0179 and einkorn HMW glutenin as 0.0012 , respectively (Table 4). Gastrointestinal digestion caused more bioactive peptides generation than gastric digestion. The highest $\mathrm{DHt}, \mathrm{A}_{\mathrm{E}}$ and $\mathrm{W}$ values among proteins of wheat and einkorn were obtained for einkorn avenin like protein as $25.442 \%$, wheat $\alpha$-gliadin as 0.288 and wheat $\gamma$-gliadin as 1.000 respectively (Table 4). 
Therefore, consumption of these wheat varieties can help to the regulation of both glucose levels and hypertension.

\section{Possible Bioactive Peptides}

PeptideRanker scores of all peptides released by digestion of wheat and einkorn proteins were determined and those greater than 0.5 were considered as possible bioactive peptides (PBPs). Table 5 shows sequences of bioactive peptides whose PeptideRanker scores greater than 0.8 .

The number of PBP produce after gastric and gastrointestinal digestion of einkorn proteins was higher than that of wheat proteins. Gastric digestion caused the release of 74 PBPs and 40 PBPs from einkorn and wheat proteins, respectively. These values for gastrointestinal digestion were 86 PBPs for einkorn proteins and 49 PBPs for common wheat proteins. The most possible bioactive peptide generation among the einkorn proteins was obtained for $\omega$-gliadin (20 for gastric digestion and 24 for gastrointestinal digestion). This was followed by $\mathrm{\gamma}$ - gliadin (15 for gastric, 18 for gastrointestinal digestion). Einkorn HMW glutenin generated the least number of PBPs for each digestion step. In the case of wheat proteins, $\alpha$-gliadin produced more PBPs for both digestion steps and $\omega$-gliadin (12 for gastric and 14 for gastrointestinal digestion) followed it. The least number of PBPs was observed in HMW glutenin.

One of the most important findings among these results was the detection of peptides having possible allergenicity according to AllergenFP program. Results showed that approximately 57\% of PBPs (42 out of 74) generated after gastric digestion of einkorn proteins might exert allergenicity. This value was $50 \%$ (20 out of 40 ) for common wheat proteins after gastric digestion. Gastrointestinal digestion did not cause any change in the probability of allergenicity of peptides. For einkorn proteins, 41 possible allergen peptides out of 86 PBPs were determined whereas this number was 23 out of 49 for common wheat proteins after gastrointestinal digestion. In addition, gastric digestion caused possible toxic peptide generation for both wheat proteins. Two of them were originated from einkorn avenin like protein (SSCQIVQYQCCQQL score:0.669; PQIPADQPTSCQNVQHQCCPQL score: 0.531) and the other was originated from wheat $\alpha$-gliadin (PAMCNVYIPPHCSTTIAPF score:0.661). However, they disappeared after intestinal digestion.

\section{Conclusion}

Wheat is a common ingredient of many food products including bread and bakery goods. However, misperception about the common wheat consumption and health disorders including obesity, diabetes mellitus, etc. causes people to consume different ancient species of wheat instead of common wheat. The result of the presented study showed that einkorn and common wheat proteins exhibited similar properties including high similarity rate and the identical bioactivities (ACE inhibitory, DPP IV inhibitory, antioxidative, stimulating vasoactive substance release, glucose uptake stimulating, antiamnestic, celiac toxic, renin inhibitory, DPP III inhibitory) of peptides generated after digestion. Most of the bioactive peptides were dipeptides and the majority of them displayed more than one 910 bioactivities including ACE inhibitory, DPP IV inhibitory or antioxidant activity. PeptideRanker scores showed that both kinds of wheat generated PBPs. However, it should be stated that their bioactivities must be examined using both in vitro and in vivo methods. Allergenicity prediction displayed that release of allergen peptides was similar for both kinds of wheat.

In conclusion, although there is a perception related to the einkorn that is healthier than common wheat, in silico digestion results did not support this perception in terms of protein profiles and peptide production. However, these results need to be supported by in vitro and in vivo studies.

\section{Acknowledgments}

This research was supported by funding from the Ege University Scientific Research Projects Coordination and by scholarships to The Scientific and Technological Research Council of Turkey.

\section{References}

Altschul SF, Wootton JC, Gertz EM, Agarwala R, Morgulis A, Schäffer AA, Yu YK. 2005. Protein database searches using compositionally adjusted substitution matrices. FEBS J 272:5101-5109. doi:10.1111/j.1742-4658.2005.04945.x

Bleakley S, Hayes M, O' Shea N, Gallagher E, Lafarga T. 2017. Predicted Release and Analysis of Novel ACE-I, Renin, and DPP-IV Inhibitory Peptides from Common Oat (Avena sativa) Protein Hydrolysates Using in Silico Analysis. Foods 6:108. doi:10.3390/foods6120108

Brandolini A, Hidalgo A. 2011. Einkorn (Triticum monococcum) Flour and BreadFlour and Breads and Their Fortification in Health and Disease Prevention. pp. 79-88. doi:10.1016/B978-0-12-380886-8.10008-X

Cavazos A, Gonzalez de Mejia E. 2013. Identification of Bioactive Peptides from Cereal Storage Proteins and Their Potential Role in Prevention of Chronic Diseases. Compr Rev Food Sci Food Saf 12:364-380. doi:10.1111/15414337.12017

Chojnacki S, Cowley A, Lee J, Foix A, Lopez R. 2017. Programmatic access to bioinformatics tools from EMBLEBI update: 2017. Nucleic Acids Res 45:W550-W553. doi:10.1093/nar/gkx273

Cooper R. 2015. Re-discovering ancient wheat varieties as functional foods. J Tradit Complement Med 5:138-143. doi:10.1016/j.jtcme.2015.02.004

Darewicz M, Borawska J, Pliszka M. 2016. Carp proteins as a source of bioactive peptides - An in Silico approach. Czech J Food Sci 34:111-117. doi:10.17221/300/2015-CJFS

Dimitrov I, Naneva L, Doytchinova I, Bangov I. 2014. AllergenFP: Allergenicity prediction by descriptor fingerprints. Bioinformatics 30:846-851. doi:10.1093 /bioinformatics/btt619

Garg S, Apostolopoulos V, Nurgali K, Mishra VK. 2018. Evaluation of in silico approach for prediction of presence of opioid peptides in wheat. J Funct Foods 41:34-40. doi:10.1016/j.jff.2017.12.022

Gebruers K, Dornez E, Boros D, Fraś A, Dynkowska W, Bedo Z, Rakszegi M, Delcour JA, Courtin CM. 2008. Variation in the content of dietary fiber and components thereof in wheats in the healthgrain diversity screen. J Agric Food Chem 56:9740-9749. doi:10.1021/jf800975w

Grausgruber H, Scheiblauer J, Schoenlechner R, Ruckenbauer P, Berghofer E. 2004. Variability in chemical composition and biologically active constituents of cerealsGenetic Variation for Plant Breeding. pp. 23-26. 
Hatanaka T, Inoue Y, Arima J, Kumagai Y, Usuki H, Kawakami K, Kimura M, Mukaihara T. 2012. Production of dipeptidyl peptidase IV inhibitory peptides from defatted rice bran. Food Chem 134:797-802. doi:10.1016/j.foodchem.2012.02.183

Hidalgo A, Brandolini A. 2014. Nutritional properties of einkorn wheat ( Triticum monococcum L .). J Sci Food Agric. doi: $10.1002 / \mathrm{jsfa} .6382$

Kẹska P, Stadnik J. 2016. Porcine myofibrillar proteins as potential precursors of bioactive peptides-an in silico study. Food Funct 7:2878-2885. doi:10.1039/c5fo01631b

Lachman J, Hejtmánková K, Kotíková Z. 2013. Tocols and carotenoids of einkorn, emmer and spring wheat varieties: Selection for breeding and production. J Cereal Sci 57:207214. doi:10.1016/j.jcs.2012.05.011

Lafarga T, Hayes M. 2014. Bioactive peptides from meat muscle and by-products: generation, functionality and application as functional ingredients. Meat Sci 98:227-239. doi:10.1016/j.meatsci.2014.05.036

Li F, Liu W, Yamaki K, Liu Y, Fang Y, Li Z, Chen M, Wang C. 2016. Angiotensin I-Converting Enzyme Inhibitory Effect of Chinese Soypaste Along Fermentation and Ripening: Contribution of Early Soybean Protein Borne Peptides and Late Maillard Reaction Products. Int J Food Prop 19:28052816. doi:10.1080/10942912.2015.1136941

Lùje H, Mùller B, Laustsen AM, Hansen Ê. 2003. Chemical Composition , Functional Properties and Sensory Profiling of Einkorn ( Triticum monococcum L .). J Cereal Sci 37:231240. doi:10.1006/jcrs.2002.0498

Minkiewicz P, Iwaniak A, Darewicz M. 2019. BIOPEP-UWM Database of Bioactive Peptides : Current Opportunities. Int J o f Mol Sci 20:1-23.

Needleman SB, Wunsch CD. 1970. A General Method Applicable to the Search for Similarities in the Amino Acid Sequence of Two Proteins. J Mol Biol 48:443-453.

Ondetti MA, Cushman DW. 1982. Enzymes of the ReninAngiotensin System and their Inhibitors. Annu Rev Biochem 51:283-308. doi:10.1146/annurev.bi.51.070182.001435

Pooja K, Rani S, Prakash B. 2017. In silico approaches towards the exploration of rice bran proteins-derived angiotensin-Iconverting enzyme inhibitory peptides. Int J Food Prop 20:2178-2191. doi:10.1080/10942912.2017.1368552

Pratley RE. 2008. Overview of glucagon-like peptide-1 analogs and dipeptidyl peptidase- 4 inhibitors for type 2 diabetes. Medscape J Med 10:171.

Rahaman T, Vasiljevic T, Ramchandran L. 2016. Effect of processing on conformational changes of food proteins related to allergenicity. Trends Food Sci Technol 49:24-34. doi:10.1016/j.tifs.2016.01.001
Shewry PR, Hey S. 2015. Do "ancient" wheat species differ from modern bread wheat in their contents of bioactive components? J Cereal Sci 65:236-243. doi:10.1016/j.jcs.2015.07.014

Šuligoj T, Gregorini A, Colomba M, Ellis HJ, Ciclitira PJ. 2013. Evaluation of the safety of ancient strains of wheat in coeliac disease reveals heterogeneous small intestinal $\mathrm{T}$ cell responses suggestive of coeliac toxicity. Clin Nutr 32:10431049. doi:10.1016/j.clnu.2013.02.003

Szerszunowicz I, Nalecz D. 2018. The Use of UniProtKB / BIOPEP for the Analysis of Oat Globulin Physicochemical Parameters and Bioactivity. Czech J Food Sci 2018:119-125.

Tu M, Cheng S, Lu W, Du M. 2018. Advancement and prospects of bioinformatics analysis for studying bioactive peptides from food-derived protein: Sequence, structure, and functions. TrAC - Trends Anal Chem 105:7-17. doi:10.1016/j.trac.2018.04.005

Tulipano G, Faggi L, Nardone A, Cocchi D, Caroli AM. 2015. Characterisation of the potential of $\beta$-lactoglobulin and $\alpha$ lactalbumin as sources of bioactive peptides affecting incretin function: In silico and in vitro comparative studies. Int Dairy J 48:66-72. doi:10.1016/j.idairyj.2015.01.008

Udenigwe CC. 2016. Towards rice bran protein utilization: In silico insight on the role of oryzacystatins in biologicallyactive peptide production. Food Chem 191:135-138. doi:10.1016/j.foodchem.2015.01.043

Udenigwe CC, Aluko RE. 2012. Food protein-derived bioactive peptides: production, processing, and potential health benefits. J Food Sci 77:R11-24. doi:10.1111/j.17503841.2011.02455.x

Udenigwe CC, Gong M, Wu S. 2013. In silico analysis of the large and small subunits of cereal RuBisCO as precursors of cryptic bioactive peptides. Process Biochem 48:1794-1799. doi:10.1016/j.procbio.2013.08.013

Valdés A, Cifuentes A, León C. 2017. Foodomics evaluation of bioactive compounds in foods. TrAC - Trends Anal Chem 96:2-13. doi:10.1016/j.trac.2017.06.004

Vercruysse L, Smagghe G, van der Bent A, van Amerongen A, Ongenaert M, Van Camp J. 2009. Critical evaluation of the use of bioinformatics as a theoretical tool to find highpotential sources of ACE inhibitory peptides. Peptides 30:575-582. doi:10.1016/j.peptides.2008.06.027

Zheng X, Li DS, Ding K. 2017. Purification and identification of angiotensin I-converting enzyme inhibitory peptides from fermented walnut residues. Int J Food Prop 20:S3326-S3333. doi:10.1080/10942912.2016.1258574

Žilić S, Barać M, Pešić M, Dodig D, Ignjatović-micić D. 2011. Characterization of Proteins from Grain of Different Bread and Durum Wheat Genotypes. Int J Mol Sci 0067:5878-5894. doi:10.3390/ijms12095878 